Final version:

Beverland, M.B., Napoli, J., and Lindgreen, A. (2007), "Industrial global brand leadership: a capabilities view", Industrial Marketing Management, Vol. 36, No. 8, pp. 1084-1093. (ISSN 0019-8501)

For full article, please contact LindgreenA@ cardiff.ac.uk

\title{
INDUSTRIAL GLOBAL BRAND LEADERSHIP: A CAPABILITIES VIEW
}

\begin{abstract}
We examine the global branding programs of five New Zealand industrial firms and identify the salient components and capabilities underpinning such programs. The cases built their respective brand identities around adaptability to customer needs and the provision of a total solution. This identity was built around five capabilities: relational support, coordinating network players, leveraging brand architecture, adding value, and quantifying the intangible. Underpinning these identity promises are five organizational level supportive capabilities: entrepreneurial, reflexive, innovative, brand supportive dominant logic, and executional capabilities. This approach resulted in global brand leadership but also reflected the fundamental differences between the $\mathrm{B} 2 \mathrm{C}$ and $\mathrm{B} 2 \mathrm{~B}$ realms.
\end{abstract}

Keywords: Brands; Brand management; Capabilities; International; Case studies.

\section{Introduction}

Brands are increasingly viewed as offering a crucial point of differentiation and a sustainable form of competitive advantage for business-to-business marketers [Beverland, 2005a; Low and Blois, 2002]. However some differences between consumer and industrial brand 
management are evident. Within consumer markets, brand managers place more emphasis on individual rather than corporate brands and direct their efforts toward minimizing the size of the brand portfolio while maximizing coverage [Mudambi, 2002]. In contrast, industrial marketers tend to focus on building the brand at the corporate level, with some experimentation at the product level, and gradually work toward increasing the size of the portfolio through acquisitions. Further, while consumer marketers highlight functional, emotional and symbolic benefits of a brand, industrial marketers primarily emphasize only functional rewards [Mudambi, 2002]. However, establishing points-of-difference for industrial brands should reflect not only the product's economic and functional features, such as quality, reliability and performance [Bendixen, Bukasa and Abratt, 2004; Michell, King and Reast, 2001], but also salient intangible associations, such as expertise and trustworthiness [Mudambi, 2002; Webster and Keller, 2004]. This is considered crucial for corporate performance as branded industrial products can provide firms with cash flow benefits and increased network power [Hague and Jackson, 1994], while enhancing corporate reputation and raising barriers to entry [Michell, King and Reast, 2001].

Brands also play an important role in the decision-making processes of business customers [Bendixen, Bukasa and Abratt, 2004; Michell, King and Reast, 2001], acting as a tool for achieving organizational consensus among the many actors involved in the buying process [Webster and Keller, 2004]. Often it is a manufacturer's reputation combined with the buyer's own level of awareness and degree of loyalty shown to the manufacturer that are important considerations in purchase decisions [Mudambi, 2002]. When brand equity is high, customers are often more prepared to pay a price premium for the product and are more likely to engage in favorable word-of-mouth communications regarding the firm and its brands [Bendixen, Bukasa and Abratt, 2004]. 
Despite the well-documented benefits of brand equity, the issue of branding in industrial marketing has received only limited research attention [Low and Blois, 2002; Mudambi, Doyle and Wong, 1997]. Moreover, no research to date has yet examined the path by which global industrial brands are created and managed. Accordingly, the purpose of this study is to examine the processes involved in the development and implementation of global brands in industrial markets. We address two fundamental questions. First, what are the core components in developing a global brand program in industrial markets? In addressing this issue, we offer empirical insight into the complex and interrelated processes of global brand building in industrial markets, which has not previously been examined [Mudambi, Doyle and Wong, 1997].

Secondly, what capabilities are necessary to implement a branding strategy across different national contexts and customer segments? This second question is paramount because in the context of global branding, loyalty is enhanced through "adapting to the needs of international segments.... and the ability to leverage existing brands into new markets" [Michell, King and Reast, 2001, p. 418]. Indeed, the ability to execute successfully in overseas markets is a key component of global brand leadership [Aaker and Joachimsthaler, 2000]. Also, the examination of capabilities is warranted because brand success comes from reinforcing the brand's meaning over time through consistent image and delivery [Michell, King and Reast, 2001; Yakimova and Beverland, 2005].

Our article is structured as follows. First, we draw on Aaker and Joachimsthaler's [2000] brand leadership framework to examine the global branding strategies of five New Zealand based industrial firms. In the spirit of grounded theory this framework was used to guide the existing inquiry (no part of the framework was guaranteed a final place in any emergent theory) [Strauss and Corbin 1998]. A method section provides detail on the sampled cases, the questions asked and the method of analysis. Findings are then presented around the 
two research questions, before concluding with the managerial implications and directions for future research.

\section{A Framework for Global Brand Leadership}

The growth of the global economy of the past 50 years has seen many organizations take their products and brands to new markets and customer groups. This has had a significant effect on the way in which brand portfolios are managed, with many multinational corporations favoring global brands [Steenkamp, Batra and Alden, 2003]. Research has shown that global brands are advantageous for several reasons. First, global brands enable organizations to take advantage of economies of scale [Aaker and Joachimsthaler, 1999]. Second, they can be used to establish synergies between countries and exploit global market segments [Holt, Quelch and Taylor, 2004]. Finally and perhaps more importantly, global brands inspire images of quality, status and prestige among consumers [Holt, Quelch and Taylor, 2004; Keller, 2003; Quelch, 1999; Steenkamp, Batra and Alden, 2003].

Developing a global brand is no easy feat. Firms must decide how to manage brands that span different geographic regions and product lines and determine who should have custody and control for the positioning and marketing of such brands [Douglas, Craig and Nijssen, 2001]. According to Quelch [1999] business-to-business brands are good candidates for global branding. Yet, to our knowledge no research exists on global branding in business-tobusiness markets. Since we are seeking to build theory, we start with Aaker and Joachimsthaler's [2000] brand leadership framework to guide our inquiry into the global branding strategies of five industrial firms (see Figure 1). In so doing, we assess the transferability of Aaker and Joachimsthaler's [2000] global brand leadership framework from a business-to-consumer to a business-to-business context. 


\section{Insert Figure 1 approximately here}

This framework is useful for examining global branding practices in industrial markets for a number of reasons. First, the process of brand building in industrial markets is complex and interrelated [Mudambi, Doyle and Wong, 1997], which involves giving consideration to both the tangible and intangible dimensions of the brand, such as company reputation, country of origin, product performance, quality associations and perceived reliability [Low and Blois, 2002; Michell, King and Reast, 2001; Mudambi, Doyle and Wong, 1997]. A unique image, supportive communications program and other components of brand value, including service levels, price and value, are also critical to industrial brand success [Michell, King and Reast, 2001]. All of these components are captured in the Aaker and Joachimsthaler [2000] framework.

Second, brand success is driven by reinforcing the brand's meaning over the long term through consistent image and delivery [Michell, King and Reast, 2001; Yakimova and Beverland, 2005], which requires supportive organizational structures and processes. For industrial brand leadership, such processes include having appropriate distribution services (i.e. logistical support and timeliness of delivery), support services and being adaptable to customer needs [Beverland and Lockshin, 2003; Ford and Associates, 2002; Low and Blois, 2002; Mudambi, Doyle and Wong, 1997]. By focusing on a targeted niche of customers and assuring those customers of a reliable supply, brand loyalty can be attained [Michell, King and Reast, 2001]. Others have identified the need for industrial marketers to develop a "bottom up and top down approach to brand building” [Webster and Keller, 2004, p. 398], which sees employees actively engaged in the brand building process. Lastly, the quality of the relationship between a firm and its buyers can facilitate the creation of intangible 
associations, which are also critical to the longer-term success of the industrial brand [Beverland, Farrelly and Woodhatch, 2004; Webster, 2000].

Thirdly, Aaker and Joachimsthaler's [2000] framework implicitly captures all the elements of the business-marketing offer, defined as "advice, adaptation, product, service and logistics" [Ford and Associates, 2002, p. 122]. The ability to adapt branding programs across nations and customer segments is believed to be critical for industrial marketers who may be unable to engage in standardized branding programs due the highly individualized needs of their business customers [Ford and Associates, 2002; Hankinson and Cowking, 1996; Keller, 2003; Webster and Keller, 2004]. A global branding strategy in industrial markets, accordingly, is likely to involve modifying either the product or service forming part of the functional brand benefits or the symbolic values of the brand proposition [Hankinson and Cowking, 1996].

\section{Method}

The use of qualitative methods is appropriate when studying complex processes [Eisenhardt, 1989] and discovery-oriented methods are appropriate in scenarios when change is radical and unpredictable [Matthyssens and Vandenbempt, 2003]. A multiple-case approach, therefore, was chosen due to the complex nature of global brand development and implementation [Mudambi, Doyle and Wong, 1997] and the need to take into account a large number of variables when studying this issue [cf: Aaker, 1996; Keller, 2003]. The study employed the multiple-case study approach of Eisenhardt [1989] who proposed that richer theory could be generated through multiple-case studies, as opposed to one-single case study.

\subsection{Sampling Procedure}


For the purposes of this study five New Zealand-based cases (all names are disguised) - Fibre Co, Meat Co, Pharma Co, Fish Co, and Dairy Co - were identified (with the help of two experts) as being relevant because of their global brand marketing successes and global market coverage. An additional reason for selecting the cases was that their global brand programs had largely been developed and implemented and each was now undergoing evolutionary change, allowing for post-hoc examination of their branding programs. These cases also fit the definition of a global strategist because they "conceive of and implement their strategies in a worldwide setting" and compete in all strategically relevant international markets [Aaker and Mills, 2005, p. 314].

Cases were selected using replication logic whereby each "case is considered akin to a single experiment" [Yin, 1994, p. 46]. Each case was therefore selected "so that it either (a) predicts similar results or (b) produces contrasting results but for predictable reasons" [Yin, 1994, p. 46]. Five cases were developed (five replications are believed to be necessary in studies of highly complex cases and to improve certainty [Yin 1994]). We ceased developing additional cases when saturation occurred - that is, when additional cases began to yield few new insights [Strauss and Corbin 1998]. Details of the sampled cases are provided in Table 1. All the firms sell directly to business buyers in overseas markets (they do not deal direct with end-consumers) and work in partnership with selected customers and suppliers to develop cobranded opportunities for certain markets.

Insert Table 1 about here

\subsection{Data Collection and Analysis}

The aim of the data-collection process was to develop rich in-depth case histories of the global brand development and the respective implementation processes. This information was 
collected using in-depth interviews and secondary data. The first author conducted interviews with a number of participants at each site, focusing on marketing managers and members of the brand team responsible for global brand management. Details of the number of interviews and time spent at each case are identified in Table 1. Each interview lasted for an average of four hours (ranging between three and eight hours). Time was also spent at each case site resulting in additional information from short conversations, observations, and other in situ techniques. Prior to each interview, publicly available secondary data and promotional information provided by each firm was reviewed to increase the author's familiarity with the cases. Questions focused on gaining a descriptive history of the motivation for global brand development, the pressures associated with global brand development, major objections, supportive processes in the implementation of the global brand program, levels of success and driving factors behind this performance. The interviews started with broad "grand tour" questions that enabled the informants to present the material on their own terms. These questions were then interspersed with specific prompts in order to gain greater insight into specific lines of inquiry such as details on particular programs. Although a short standardized guide was used at each site (focused on the aforementioned topics) to drive the interview, the process was also driven by emerging topics derived from each interview and the unique aspects of each case.

Following the interviews, further information provided by the informants or sourced by the authors was examined. Drawing on secondary data and multiple interviews in each case helped develop rich insights across multiple-case studies and provided the basis for greater transferability of the findings to other contexts [Eisenhardt, 1991]. This involved a widespread search of published documents, McKinsey reports, industry conference proceedings, books and conference papers, websites (these included customer feedback on each program and examples of customer focused branded new products) and a search of a 
local News Index database to cover 15 years of history of each firm. With the unit of analysis being each case studied, the information from each interview and the secondary sources were combined into one case manuscript. In total this process resulted in a transcript of 245 pages. The final cases detailed the birth and growth (and in the Meat Co case, decline) of all brands up until 2004.

The cases were analyzed using Eisenhardt's [1989] method of within-case and crosscase analysis. The first step involved assessing the usefulness of the Aaker and Joachimsthaler [2000] framework in the business-to-business context. We did this by allocating the components of each case's brand program to the various categories of the framework to assess fit (this information is provided in Table 2). Following this, each case was analyzed to gain a richer understanding of the processes each underwent to move towards a global brand. As each case achieved different degrees of global brand success the cases were then compared and contrasted to analyze similarities and differences and to gain greater understanding of the processes involved. Cross-case analysis is essential for multiple case studies [Yin, 1994]. At the same time, theoretical categories were elaborated on during open and axial coding procedures [Strauss and Corbin, 1998]. Lastly, to gather a holistic and contextualized comprehension of how the industrial marketers approach global brand development, in the analysis we tacked back and forward between literature and data, which led to the development of a number of theoretical categories [Spiggle, 1994].

Throughout the study, a number of methods for improving the quality of the research were adopted. Consistent with the recommendations of interpretive researchers [Lincoln and Guba, 1985], grounded theorists [Strauss and Corbin, 1998] and previous case-based research in business-to-business marketing [Beverland and Lockshin, 2003; Flint, Woodruff, and Gardial, 2002] we applied the criteria of credibility, transferability, dependability, confirmability, integrity, fit, understanding, generality, and control to improve the 
trustworthiness of the findings. These criteria were applied through: using experts to help select the cases, conducting multiple interviews, having three researchers provide independent interpretations of the findings, and allowing respondents to provide feedback on initial findings. The interviews were conducted by the same interviewer (the first author) and colleagues performed independent coding of the transcripts, which also helped to reduce the role of bias [Lincoln and Guba, 1985; Strauss and Corbin, 1998].

\section{Findings}

We firstly assessed the transferability of the Aaker and Joachimsthaler [2000] global brand leadership framework to a business-to-business context. The results for each case are presented in Table 2. Although we identify the existence of the four components of the Aaker and Joachimsthaler framework, we found substantial differences in the approaches used by the industrial firms. Our findings explain these differences and address our two research questions.

Insert Table 2 in here

\subsection{A capabilities centric brand identity}

The sampled firms sought to position their brands around capabilities, using terms like "A total solutions provider." Brand identity refers to the key words or phrases that sum up the core values of a brand [Keller, 2003], which provide clear guidance for action, resonate with key stakeholders and create a point of meaningful differentiation for a firm [Agres and Dubitsky, 1996]. In a B2C context, the central challenge facing global brand managers is the extent to which they adapt their brand's identity and supportive marketing program to the needs of individual markets [Aaker and Joachimsthaler, 2000]. Our B2B cases also faced challenges relating to adaptation versus standardization, but at a customer rather than a market 
level. Such a challenge is consistent with the dominant view of business-marketing customers and segmentation whereby adaptability to each individual customer is seen as the norm [Ford and Associates, 2002], and challenges views that brand management principles from the B2C realm can easily be transferred to the B2B context [cf: Webster and Keller, 2004].

All of the cases identified adaptability to key customers as central to global brand success. Adaptability was referred to with terms such as "solutions providers" and was a customer driven approach to brand identity definition. For example, Pharma Co identified the need to provide a customized solution for large customers, focusing on all aspects of the business marketing mix including ongoing advice for improvements, supportive marketing material, logistical support, product improvements and service. For Pharma Co, such pressures from key customers were driving mergers among their competitors because medium sized players struggled to provide the scope of services desired by buyers. For the rest of the firms, the ability to provide a customized solution (and update that solution) was central to their global brand promise. They also noted there were tensions between their desired positioning, their desire to build a consistent brand image, and the need to adapt to individually important customers. For example:

"If you start looking at the German market it's pretty much the traditional meat market and if you are a hunted meat dealer in Europe it is a darn sight easier to sell our meat as local game meat than it is to try and raise the idea that it came from New Zealand and it might be farm raised and a lot of other things that cause a lot of concerns for the traditional consumer." (Meat Co)

The quotation from the Meat Co brand manager identifies that key German customers prefer to package up meat from a number of global suppliers into their own customized brand targeted at consumers of "hunted meat." As such, Meat Co's image of farm-raised animals 
from New Zealand does fit well with this customer's needs. Yet, this customer remains critical to Meat Co, as Germany is their largest volume market. Other firms faced similar problems. For example Fibre Co will only allow their ingredient brand logo to be placed inside of garments made by their customers that share Fibre Co's desired up-market position. Although this strategy would be consistent with Aaker and Joachimsthaler's [2000] framework (in that positioning would inform target segments), it would also fail to provide the complete solution required by Fibre Co's customers who require supplies for a wide range of brands, many of which are targeted at low price segments. Such customer's prefer to work with a few reliable suppliers, and therefore Fibre Co must adapt to their needs and provide a wider solution than that allowed for with their desired brand position. In doing so, they reinforce their relationship status and ensure their brand's success. Because of such tensions, all the cases placed adaptive (and other) capabilities at the heart of their brand identities. For example:

"We recognize that at that top end of the market the production and manufacturing companies are different, so we do special things with each of them. Their face to the market is completely different from ours so we have to do unique things for each of them. The majority of the companies we work with have their own ideas, many have marketing teams and so we try and work in with them and give them some ideas. We get involved with a lot of the design work in terms of point-of-sale material and things like that." (Fibre Co)

Such a finding is subtly different to the Aaker and Joachimsthaler [2000] framework that identifies the need to adapt the brand's image, positioning and supportive marketing programs across different cultures / segments. As a result, B2C firms should build capabilities that allow for such adaptation, or preferably, innovative solutions that balance standardization 
and customization. In contrast, B2B firms face a different business environment involving fewer (and often larger) powerful customers, each of which have individual demands that reflect their different business strategies [Ford and Associates, 2002]. Rather than separate global brand identity and global brand leadership capabilities the sampled cases effectively placed their capabilities at the heart of their brand identity and position. Reinforcing this brand identity were five capabilities: relational support, coordinating network players, leveraging brand architecture to provide a total solution, adding value to the customer's brand, and quantifying the intangible.

\subsubsection{Relational support}

All of the cases stressed the importance of relationships with key customers in their brand identities (see Table 2). Thus relationship creation and management was central to a brand's promise to customers. For example:

"They want you to come to them with solutions. The great thing about being a leading brand is that customers know you can give them point of sale material, and if you really know what you are doing and analyze it carefully, you can suggest things to them like changing the way they manage the category on the shelves to improve margins for them and so on..." (Dairy Co).

The quotation above identifies the role of relational adaptation in positioning the brand with customers. The result of this form of brand investment is that Dairy Co can play a more active role in managing the relationship [cf: Beverland, Farrelly and Woodhatch, 2004], leading to further commitment and loyalty [Morgan and Hunt, 1994]. Pharma Co identifies being an "effective developer of dairy ingredient partnerships" in their brand identity. The motivation for this positioning includes customer demand for "integrated and tailored 
solutions." This positioning then influences strategy by leading Pharma Co to seek out likeminded partners and adapt to existing customers in order to spur growth and drive product innovation. The view that relational capabilities are central to brand identity is also captured in the following passage from Fibre Co.

"What we have done from a research and development point of view is work directly with these prestigious companies, particularly the Italian ones. One of the most prestigious vertical spinner and weavers in the world is Loro Piana. We approached Loro Piana early on because they produced fabrics for 180 years. We went to them with our story and told them what we were trying to achieve and they decided to do some trials and make $100 \%$ [corporate brand name] woven fabrics. That partnership resulted in a product called "[brand name]", which is a brand name they gave to a range of $100 \%$ New Zealand fibre.” (Fibre Co)

In summary, the sampled cases reinforced their positioning as solution providers by emphasizing their relational capabilities in their brand identities. As the above passage identifies, selectively working with key business buyers involved adaptation. This ability was then weaved into a brand story that then influenced their day-to-day strategies across different international markets. By placing relational capabilities at the heart of the "brand story" (or identity [Keller, 2003]), firms can maintain global image consistency while also adapting to markets and customers. In contrast to the Aaker and Joachimsthaler [2000] framework, B2B firms position themselves as adaptors, rather than adapt the brand image and supporting programs across different market contexts. Relational capabilities focused primarily on oneto-one dyadic relationships. The cases also stressed their network capabilities in their brand identities. 


\subsubsection{Coordinating network players}

The sampled cases often operated in complex networks (for example, the cases often dealt with demand chains involving up to 11 (range 4-11) different partners). Much of this had to do with the need to manage multiple supply and distribution chains across many nations. Also, because these cases were agribusinesses they also had to manage relationships with other stakeholders including government agencies, the specialist press (such as food critics), transporters, processors, and in some cases sellers such as auctioneers. The ability to coordinate network players in order to reinforce the brand's position and ensure effective execution was another capability central to each brand's identity. For example:

"We have tried to get them all around the table. In Japan we often have a top maker, spinner, weaver, wholesaler and retailer who have never met each other before. Each person is getting more and more open because they know it is to everybody's advantage to do so. What we are trying to do is just get that information flying, which is useful if people need to overcome problems." (Fibre Co)

The use of network capabilities reinforced each brand's identity of a total solutions provider. This strategy represented a substantial change from past practice. In the sampled cases, network members had a history of distrust and conflict. In particular, each member was viewed as an unnecessary “cost," and relationships were arm's length and antagonistic. For example, Meat Co traditionally sought power over processors and buyers by restricting supply (resulting in increased prices). However such actions either caused some processors to go out of business, or to make cuts in quality. The other cases historically took the same approach out of the belief that each player could simply pass along increased prices to other network partners. Such a strategy ultimately undermined the viability of some industries and reduced brand value for each case. 
Leveraging networks was also essential to brand positioning. For example, Fibre Co is leveraging the network position of Loro Piana to increase their brand profile and ultimate strength: "The thing about Loro Piana is by getting with them very early, they are opinion leaders, if they do something, others follow, and so by them getting into bed with us and being dedicated to us means that other textile companies start sitting up and taking notice of what we do." Fibre Co also sought to spread their message to the public, potential business customers and end-consumers as a means of enhancing the brand's value with business buyers. This would create a pull effect through the channel and assist their immediate business buyers to create demand [cf: Webster, 2000].

Finally, Fish Co (which stressed leveraging their global network position in their formal brand identity documents) worked directly with government agencies charged with sustainably managing fish stocks, and consumer agencies that monitored fish labeling practices. In both cases, Fish Co brought all partners together to ensure the uptake of sustainable practices, and the development of standardized terms for different fish (for example, Fish Co is currently working to establish standard species labeling across Australia where such names differ in each state). Fish Co did this out of a belief that this would create the basis for greater customer certainty and trust in their brand, and improve public perceptions in some countries of the industry.

Such adaptations were central to ensuring global market success, and were seen as an essential part of each brand's reputation.

\subsubsection{Leveraging brand architecture to provide a total solution}

Brand architecture refers to the management of multiple brands and the role of each brand and sub-brand within the portfolio [Aaker and Joachimsthaler, 2000]. A well-conceived architecture can help focus an organization's marketing efforts and guide decision making 
with respect to how, or if a brand should be extended, deleted or added to a product line [Aaker and Joachimsthaler, 2000]. We found that brand architecture was used to manage the competing desire for standardization and adaptability. Both firms developed corporate brands and then applied some or all of the attributes of their corporate identity to sub-brands and endorsed brands (see Table 2). In contrast to Aaker and Joachimsthaler [2000], the ability to develop brand architectures, adapt them, and leverage them for mutual advantage was another capability stressed within each brand's identity program. For example:

"We are pretty much at the top end of it and in saying that, we have the gourmet cheese for cheese boards and that sort of thing, but we also have a lot of ingredient products that the chef will use as well and then we go right down to the basic commodities with the food service range. We do 1.6-kilo blocks of Cheddar and Edam and pizza cheese for that market. You'll never hear about it publicly because that's just not where we are, so in that area we're looking to provide a pretty comprehensive package...." (Dairy Co)

The development of a complete range of products branded under a corporate brand was used to reinforce the brand's adaptive and total solution identity. The other brand's used a similar strategy (see Table 2 and section 4.1). For example, Meat Co had a corporate brand for high-end niches, while a country-of-origin value-based brand targeted large retailers. In this latter situation, only a few aspects of the corporate brand were used. Meat Co also endorsed brands by franchising out their corporate program to local operators who met the relevant quality standards and targeted high-value niches. The use of endorsed brands helps forge a global corporate identity and increase brand visibility, while providing reassurance to customers that the company is reliable [Douglas, Craig and Nijssen, 2001].

\subsubsection{Adding value to the customer's brand}


As part of their positioning the sampled brands also stressed adding value to their customer's in their brand identities. This went beyond performance related benefits and included the focus on how these ingredient brands (and their associated images) could ultimately add value to the final branded product produced by the customer. It also included focusing on capabilities helpful to improving the customer's position (for examples see the Dairy Co quote on managing categories in section 4.1.1 and Fibre Co's development of exclusive cobranded products with Loro Piana in section 4.1.2). For example:

"We're there to consult and sell to chefs, and to do that you have to be credible. You've got to know what you're talking about and a lot of our staff are able to help the chef in designing menus, recommending product and all of those added value things, such as being proactive in keeping chefs up to date with new products." (Dairy Co)

Dairy Co's positioning as a supportive brand partner in their customer's business was replicated in the other four cases. Value was added by building a broad public profile of important attributes of each brand's programs in order to encourage customer/consumer pull and favorable press coverage. For example, all the brands studied also drew on aspirational images associated with natural production, farm, region and country of origin, animal welfare and health. The literature on business-to-business branding to date has downplayed the role of aspirational imagery [Lynch and de Chernatony, 2004] because such images primarily appeal to buyer's emotions and are thought to be less useful in an industrial marketing context where decisions are believed to be more rational [Bendixen, Bukasa and Abratt, 2004]. In contrast we find that aspirational imagery adds another layer of nuance and value to business-tobusiness brands, providing a source of competitive advantage and adaptation both to the brand marketer, and the customer's brand. 
Three other added value capabilities were stressed: process innovations to create product quality leadership, product innovations, and promotional support. Quality leadership has formed a central part of each case's brand identity. Typical of such approaches were campaigns developed around themes that stressed total quality from source to customer. Examples included tag lines like "From Pasture to Plate" (Meat Co) and "From Fleece to Garment" (Fibre Co). The level of investment in new products was also stressed, as were the respective innovative capabilities of each firm. Fish Co for example, stresses its cutting edge processing on both land and sea as part of its strategy to develop the highest quality and freshest product for its business customers. By stressing such capabilities the brands communicate ongoing commitments to their business customers and increase certainty over future intentions, both of which are critical to ongoing loyalty [Beverland and Lockshin, 2003; Ford and Associates, 2002].

All the cases positioned themselves as potential strategic partners for key customers whereby joint innovation and branding opportunities could create new sources of value for both parties. Pharma Co stresses the need to roll out new products in order to support customer relationships. Both Fish Co and Dairy Co do likewise. Fibre Co had the most developed strategy of all the cases in this regard with a number of exclusive co-branded product lines developed in conjunction with key customers that saw them create new markets both for their raw materials and the customer. This included developing material for washable suits, a blend of denim and wool, and a blend of possum fur and wool.

All the brands invested in significant public relations events that profiled their own brands and often those of their customers. Such strategies were seen as adding significant value to their customer's business and each case emphasized their track record of such activities in their brand identities. Examples of such activities included presenting world leaders with gifts of Fibre Co cloth to be made into suits, sponsoring fashion shows, 
nutritional conferences, wine and food events, associating the product with key users (such as high profile chefs and elite sports people). Such programs added value to customers by creating consumer and network member pull, and helping to garner favorable press coverage, thus increasing the status of each customer's brand.

\subsubsection{Quantifying the intangible}

As well as seeking further points of differentiation through aspirational imagery, the cases all sought to quantify previous intangible performance aspects of their offer. The performance of products received particular attention because for the most part few agribusinesses had not paid much attention to this issue, preferring subjective performance standards. For example, assessments of product quality for wool have traditionally been made by "feel" - where an expert classer assesses the quality (in terms of strength and fineness) of the fibre. Fibre Co developed the scientific means to objectively measure wool quality and therefore had the ability to meet customers exacting requirements and make informed decisions on raw material sourcing. Such a capability formed part of the brand's reputation and set the standard for the industry as a whole. The other cases also sought to develop quantifiable customer relevant quality standards, including standard cut sizes for meat, grades of seafood, and milk based quality.

Another form of this capability involved developing market metrics to identify the value of the brand. For example:

"These supermarkets measure the return per square foot of per foot of shelf space, and if you know that, you have got to manage products that aren't moving in order to support their business and your status at category manager...” (Dairy Co) 
Dairy Co acts as a category manager for key retail outlets and ensures their ongoing brand status by becoming more adept at performance metrics. This capability set the standard for practice with this retail group. Measuring results and measuring brand performance are also sub-components of the brand building programs. Estimating the relative worth of a brand can be achieved by calculating the incremental increase in price a customer is prepared to pay for a branded product compared to an equivalent unbranded product [Park and Srinivasan, 1994]. The cases performed differently in each of these components. Meat Co failed to invest in a separate price schedule for branded product and therefore was unable to prove the brand raised the prices in comparison to commodity meat. As a result, Meat Co was unable to sustain internal support for the program and saw its funding cut, resulting in a decrease in equity (estimated using the price per kilo received) and a fall in reputation. In contrast the other cases developed specific metrics to measure customer-based brand equity. Examples of this include Pharma Co's commitment to “measure a job well done through our customer's eyes." This enabled them to compare the value of their programs with those of competitors, resulting in a preference for their brand because this would enhance the customer's business, and / or build value of co-branded products. Such quantification also enabled customers to accurately evaluate the relationship specific investments made by each of the sampled firms. Finally, measures consistent with the Aaker and Joachimsthaler [2000] framework were also developed as identified in Table 2.

\subsection{Firm-level global brand supportive capabilities}

The capabilities that lay at the heart of each case's brand identity were further underpinned by five organizational level capabilities. These capabilities were not communicated directly via brand supportive communications but instead allowed the organizations sampled to deliver on their brand promise [cf: Aaker and Joachimsthaler, 2000; Yakimova and Beverland, 2005]. 
Since we abstracted these capabilities from those identified above (as well as other primary case material) we will refer to the examples provided above in our discussion of each capability. We also note that the following five capabilities operated in a systemic way and thus it is the bundle of these five capabilities that drives the brand leadership position, rather than any single capability in isolation [cf: Kaleka, 2002].

\subsubsection{Entrepreneurial capabilities}

Marketplace activeness is critical for long-term business success, and central to an entrepreneurial outlook [Beverland, 2005b]. The passages identified in the previous sections provide a stream of examples of entrepreneurial activity. These firms were all active in adapting to, and leading customers in order to reinforce their brand position. Likewise, they gathered sources of market intelligence and other customer relevant feedback to inform future strategic moves. The targeting of lead users, the use of co-branding, public relations, lobbying, product innovation, and partner support are further evidence of ongoing entrepreneurial activities that seek to enhance customer value [cf: Beverland and Lockshin, 2003; Flint, Woodruff and Gardial, 2002], ultimately increasing the reputation and equity of the brand. A key component of such an entrepreneurial outlook is the ability to question longheld assumptions about business practice [Beverland, 2005b].

\subsubsection{Reflexive capabilities}

The firms underpinned their brand programs with a learning culture that helped anticipate change, encourage risk taking, focus on ongoing value creation, monitor customers and competitors, question long held beliefs, learn from mistakes and successes, and ensure entrepreneurial activity [Lukas and Bell, 2000]. Firms need to build learning capabilities that allow for exploration and exploitation given that the business marketing offer includes not only products but also service, logistical support, adaptability and advice [Ford and 
Associates, 2002]. For example, Fibre Co developed a promotional competition focusing on producing the finest bale of wool in one season, which was then sold through the auction system to gain the highest price. For example:

"It was a promotional exercise. It was not too high a price, because there can only be one bale, so it barely affects your total wool price. We conducted a special competition / auction for the growers. We invited buyers from Europe and Asia to buy the finest bale and that got us very good press coverage. I think it's good for the growers too. Only a very small part of a grower's total clip is of this ultra fine quality [15 to 16 microns], but everybody wants to be the winner so this drives change in the industry. It drives people to make improvements in their farms and systems. The manufacturer gets his money back because he markets it very exclusively and each of his suits will have a special label and special marking on it." (Fibre Co)

The above quotation identifies a number of key points in regards to global brand building programs. Firstly, it reuses the auction system in a new way (for special promotion), it reinforces commitment to the brand program with members, adds value to clients, gains widespread publicity for the Fibre Co brand and reinforces commitment to continuing improvements in quality. Finally, it reinforces the brand by enhancing its exclusive positioning. Meat Co had a similar program with a branded restaurant competition, which achieved the same benefits (as did using a network of chefs). Such programs are examples of reflexive thinking that challenges preconceived notions about the structure of the market, resulting in innovative solutions. All the cases were leaders in this regard given that they were leaders in developing brands for products long considered by others to be low value commodities. 


\subsubsection{Innovative capabilities}

Product innovation was central to the brand identities of all the cases. Underpinning this were significant investments and capabilities in product innovation and product leadership (which is believed central to brand equity [Keller, 2003]). The cases invested in three forms of innovation - product, process, and marketing innovations. This sits in contrast to other commodity producers that typically focus solely on process innovations [Beverland, 2005a]. Product innovations took the form of new product types such as blended fibre products, new milk-based protein strains, new styles of meat, new processed fish products, and new dairy products. These were developed both internally in each firm and in conjunction with key business customers. Process innovations took the form of quality and efficiency improvements that ensured ongoing performance and price leadership. Some of these could be seemingly small changes that had large results. One example included changing the way animals were transported in order to reduce stress and therefore improve meat and hide quality. Finally, marketing innovations involved co-branding, public relations, guerilla style campaigns, and the use of aspirational imagery to enhance the status of commodity products.

\subsubsection{Brand supportive dominant logic}

To support the brand's position and promise over time the cases built brand supportive dominant logics. A dominant logic is "the way in which managers [in a firm] conceptualize the business and make critical resource allocation decisions." [Prahalad and Bettis, 1986, p. 490]. This involved focusing the firms' cultures and structures around the brand. The identification of a brand supportive dominant logic goes beyond the supportive systems and structures identified by Aaker and Joachimsthaler [2000] to include the firms' overall culture and outlook. We believe such a difference can be explained by the fact that the cases relied heavily on corporate brands rather than a range of single, disconnected product brands 
[Mudambi, 2002]. These structures enable adaptation and reinforcement of the brand's position and protect the brand from internal cost cutting exercises and abuse. Central to this logic was to build internal ownership for the brand.

All the cases sought to build internal ownership for their brand programs. They did this through aligning reward, training and hiring policies with the brand's desired positioning, providing ongoing communications about the brand and its customers, and developing systems to ensure consistency of delivery. For example, Fibre Co encouraged its key suppliers to adopt a longer-term outlook, dropping commodity based pricing for the greater certainty of long term fixed price contracts. The inability of Meat Co to do the same saw the brand suffer as price and supply fluctuations undermined the brand's central promise of adapting to customer needs.

\section{$\underline{4.2 .5 . ~ E x e c u t i o n a l ~ c a p a b i l i t i e s ~}$}

The final capability involved the ability to execute brand supportive programs. This is related to Aaker and Joachimsthaler's [2000] "achieving brilliance" sub-component of brand building programs. The cases were leaders in launching new products, new campaigns, managing relationships, adapting to current and new customers, and entering and growing new markets. They also built substantial expertise in areas such as supply chain and category management. A final executional capability related to the ability to balance the competing demands for brand stability and customer adaptation. This capability was achieved through an emphasis on implementation at all stages of the planning process, working closely with customers to increase the chances of launch success for new products and new marketing initiatives, and obtaining ongoing feedback on performance to allow for adjustments in brand programs.

\section{Discussion}


We provide the first systemic analysis (to our knowledge) of global industrial branding practice, identifying key brand identity attributes and firm-level global brand supportive capabilities. The identification of firm-level processes underpinning successful brand practice adds to our emerging understanding of branding in business markets [Michell, King and Reast, 2001], while demonstrating the fundamental differences in building and growing global brands between the B2B and B2C contexts. The findings also add to calls for both top down and bottom up approaches to branding in business markets by identifying the importance of a supportive organizational context to ongoing brand success [Webster and Keller, 2004].

Global branding is particularly relevant in industrial markets given the global strategies adopted by many B2B firms [Anderson and Narus, 2004], which can be contrasted to those adopted by B2C firms. In consumer markets, customer fragmentation, increased competition [Agres and Dubitsky 1996], and customer mobility [Alden, Steenkamp and Batra 1999] combined with the rise of retailer power [Barron and Hollingshead 2004] have contributed to the push for global brand leadership. Global brands are seen as powerful institutions and ascribed certain characteristics, such as higher prestige, product quality, reliability and innovativeness, by consumers [Holt, Quelch and Taylor 2004; Steenkamp, Batra and Alden 2003], providing global brands with a source of competitive advantage and market power [Dawar 2004; Motameni and Shahrokhi 1998].

Consequently, the pursuit of global growth opportunities has had a significant effect on the way in which consumer brands are managed, with marketers focusing on such issues as how brand portfolios should be structured, the level of coordination most appropriate for managing brands across countries and the degree of consistency in brand positioning across countries [Douglas, Craig and Nijssen 2001]. The existence of relatively homogenous customer groups across markets may see a standardized market offer developed [Steenkamp, Batra and Alden 
2003], while a separate marketing program may be developed for brands in different stages of their development cycle across markets [Quelch 1999]. Generally, B2C firms will attempt to standardize the strategic elements of the marketing mix and adapt those aspects where there is a higher level of interface between the consumer and the company [Quelch 1999].

The context of industrial marketing is very different to this scenario. Industrial markets are characterized by fewer segments, fewer customers, derived demand, complex networks, and customers with specific needs [Webster and Keller, 2004]. The business marketing offer involves more than just product/service excellence, but also includes the ability to adapt to customers' needs, offer specific advice on customer problems, and maintain effective logistical systems [Ford and Associates, 2002]. The findings offer support for a different approach to branding in industrial markets and thus limit the transferability of B2C global frameworks into the B2B context.

We also add to the growing understanding of brand meaning in business markets. Research to date identifies the centrality of "reputation" to industrial brand identity [Bendixen, Bukasa and Abratt, 2004; Michell, King and Reast, 2001; Mudambi, 2002]. By identifying the centrality of adaptability to brand identity and five reinforcing identity-based capabilities we unpack this term, adding further to our knowledge of what makes up reputation. The sampled cases positioned their brands on the basis of provable reputations for delivering value to customers and reinforced these commitments over time.

\subsection{Limitations and Future Research}

There are a number of limitations to our research. Firstly, the context of agribusiness may limit the transferability of the results. Future research in other industry contexts is therefore needed to uncover the full range of possible identity related attributes and supportive capabilities required to support global branding programs in industrial markets. The cases 
studied targeted customers who required adaptation and customized support. Future research could examine whether these results transfer to managers of brands dealing with customers who demand lower levels of adaptation. Also, research could examine the differences in global brand building for B2B firms using different brand architecture strategies given that we examined firms using a single corporate brand. Finally, future research could establish clear relationships between each brand identity attribute and supportive firm-level capability (that is, which capabilities are necessary for supporting certain brand promises). Such research could also examine the relevant importance to brand equity of the different capabilities included in brand identity, and the supportive capabilities.

\subsection{Managerial Implications}

The article provides a number of practical insights into the practice of global branding in industrial markets. Firstly, each case built a brand around adaptation to key customers and reinforced this positioning with an identity based on five capabilities. This suggests managers need to go beyond developing simple corporate identities in favor of rich brand identities that build the firm's reputation as a solutions provider in global markets. Secondly, such brands must be supported by a number of firm-level capabilities. In particular, brands must build supportive dominant logics that place the brand's identity at the heart of the organization. Given the need to work across many functions to successfully execute business marketing programs (including brand positioning), managers are encouraged to invest in internal marketing programs that educate firm members on the importance of the brand, and brandrelevant activities. This needs to be reinforced with a reconfiguration of human resource control systems to ensure buy-in to the brand program. 


\section{References}

Aaker, David A. [1996] Building Strong Brands, New York: Free Press.

Aaker, David A. and Erich Joachimsthaler [1999] "The Lure of Global Branding," Harvard Business Review, Vol. 77, No. 6, pp. 137-144

[2000] Brand Leadership, New York: Free Press.

Aaker, David A. and Michael Mills [2005] Strategic Market Management Pacific Rim Edition, Milton, QLD: Wiley.

Agres, Stuart J. and Tony M. Dubitsky [1996] "Changing Needs for Brands," Journal of Advertising Research, Vol. 36, No. 1, pp. 21-30.

Anderson, James C. and James A. Narus [2004] Business Market Management, $2^{\text {nd }}$ Edition, Singapore: Prentice Hall.

Alden, Dana L., Jan-Benedict Steenkamp and Rajeev Batra [1999] "Brand Positioning Through Advertising in Asia, North America and Europe: The Role of Global Consumer Culture," Journal of Marketing, Vol. 63, No. 1, pp. 75-87.

Barron, Jennifer and Jim Hollingshead [2004] "Brand Globally, Market Locally," Journal of Business Strategy, 25(1): pp. 9-15

Bendixen, Michael, Kalala A. Bukasa and Russell Abratt [2004] "Brand Equity in the Business-to-Business Market," Industrial Market Management, Vol. 33, No. 5, pp. 371-380.

Beverland, Michael B. [2005a]. "Creating Value for Channel Partners: The Cervena Case,' Journal of Business \& Industrial Marketing, Vol. 20, No. 3, pp. 127-135. [2005b] "Relationships and Flexibility: Synthesizing Inertia and Activity into Sustainable Strategy,” Industrial Marketing Management, Vol. 34, No. 6, pp. 577-589.

Beverland, Michael B., Francis Farrelly and Zeb Woodhatch [2004] "The Role of Value Change Management in Relationship Dissolution: Hygiene and Motivational Factors," Journal of Marketing Management, Vol. 20, No. 9, pp. 927-940.

Beverland, Michael B. and Lawrence S. Lockshin [2003] "A Longitudinal Study of Customers' Desired Value Change in Business-to-Business Markets," Industrial Marketing Management, Vol. 31, No. 8, pp. 653-666.

Dawar, Niraj [2004] “What are Brands Good For?”, Sloan Management Review, Vol. 46, No. 1, pp. 31-37.

Douglas, Susan P., C. Samuel Craig and Edwin J. Nijssen [2001] "Executive Insights: Integrating Branding Strategy Across Markets: Building International Brand Architecture," Journal of International Marketing, Vol. 9, No. 2, pp. 97-114.

Eisenhardt, Kathleen M. [1989] "Building Theories from Case Study Research," Academy of Management Review, Vol. 14, No. 4, pp. 532-550. 
[1991] "Better Stories and Better Constructs: The Case for Rigor and Comparative Logic," Academy of Management Review, Vol. 16, No. 3, pp. 620-627.

Flint, Daniel J., Robert B. Woodruff and Sarah Gardial [2002] "Exploring the Phenomenon of Customers' Desired Value Change in a Business-to-Business Context," Journal of Marketing, Vol 66, October, pp. 102-117.

Ford, David and Associates [2002] The Business Marketing Course: Managing in Complex Networks, Chichester: John Wiley \& Sons.

Hague, Paul and Peter Jackson [1994] The Power of Industrial Brands, Maidenhead: McGraw-Hill.

Hankinson, Graham and Philippa Cowking [1996] The Reality of Global Brands, Hempel Hempstead: McGraw-Hill.

Holt, Douglas, John A. Quelch and Earl L. Taylor [2004] "How Global Brands Compete," Harvard Business Review, Vol. 82, No. 9, pp. 1-9.

Kaleka, Anna [2002] "Resources and Capabilities Driving Competitive Advantage in Export Markets: Guidelines for Industrial Exporters," Industrial Marketing Management, Vol. 31, No. 3, pp. 273-283.

Keller, Kevin L. [2003] Strategic Brand Management, Upper Saddle River, New Jersey: Prentice Hall / Pearson Education International.

Lincoln, Yvonna S. and Egon Guba [1985] Naturalistic Inquiry, Beverly Hills, California: Sage Publications.

Low, John and Keith Blois [2002] "The Evolution of Generic Brands in Industrial Markets: The Challenges to Owners of Brand Equity," Industrial Market Management, Vol. 31, No. 5, pp. 385-392.

Lukas, Bryan A. and Simon J. Bell [2000] "Strategic Market Position and R\&D Capability in Global Manufacturing Industries,” Industrial Market Management, Vol. 29, No. 6, pp. 565-574.

Lynch, Joanne and Leslie de Chernatony [2004] "The Power of Emotion: Brand Communication in Business-to-Business Markets," Journal of Brand Management, Vol. 11, No. 5, pp. 403-419.

Matthyssens, Paul and Koen Vandenbempt [2003] "Cognition-in-Context: Reorienting Research in Business Market Strategy," Journal of Business and Industrial Marketing, Vol. 18, No. 6/7, pp. 595-606.

Michell, Paul, Jacqui King and Jon Reast [2001] "Brand Values Related to Industrial Products,” Industrial Marketing Management, Vol. 30, No. 5, pp. 415-425.

Morgan, Robert M. and Shelby D. Hunt [1994] "The Commitment-Trust Theory of Relationship Marketing," Journal of Marketing, Vol. 58, No. 3, pp. 20-39. 
Motameni, R. and Manuchehr Shahrokhi [1998] "Brand Equity Valuation: A Global Perspective," Journal of Product and Brand Management, Vol. 7, No. 4, pp. 275-90

Mudambi, Susan [2002] "Branding Importance in Business-to-Business Markets: Three Buyer Clusters,” Industrial Marketing Management, Vol. 31, No. 6, pp. 525-533.

Mudambi, Susan M., Peter Doyle and Veronica Wong [1997] "An Exploration of Branding in Industrial Markets," Industrial Market Management, Vol. 26, No. 5, pp. 433-446.

Park, Chan S. and V. Srinivasan [1994] "A Survey-based Method for Measuring and Understanding Brand Equity and its Extendibility," Journal of Marketing Research, Vol. 31, No. 2, pp. 271-288.

Prahalad, C.K. and Richard A. Bettis [1986] "The Dominant Logic: A New Linkage Between Diversity and Performance," Strategic Management Journal, Vol. 7, No. 6, pp. 485502.

Quelch, John A. [1999] “Global Brands: Taking Stock,” Business Strategy Review, Vol. 10, No. 1, pp. 1-14.

Spiggle, Susan [1994] "Analysis and Interpretation of Qualitative Data in Consumer Research," Journal of Consumer Research, Vol. 21, No. 3, pp. 491-503.

Steenkamp, Jan-Benedict, Rajeev Batra and Dana L. Alden [2003] "How Perceived Brand Globalness Creates Brand Value," Journal of International Business Studies, Vol. 34, No. 1, pp. 53-65.

Strauss, Anselm and Juliet Corbin [1998] Basics of Qualitative Research, 2nd ed., Newbury Park, CT: Sage.

Webster, Frederick [2000] "Understanding the Relationships among Brands, Consumers and Resellers," Journal of Academy of Marketing Science, Vol. 28, No. 1, pp. 17-23.

Webster, Frederick and Kevin L. Keller [2004] "A Roadmap for Branding in Industrial Markets,” Journal of Brand Management, Vol. 11, No. 5, pp. 388-402.

Yakimov, Raisa and Michael B. Beverland [2005] "Organizational Drivers of Brand Repositioning: An Exploratory Study," Journal of Brand Management, Vol. 12, no. 6, pp. 445-460.

Yin, Robert K. [1994] Case Study Research: Design and Methods, $2^{\text {nd }}$ Ed., Thousand Oaks, CA: Sage. 
Figure 1 Global Brand Leadership Framework

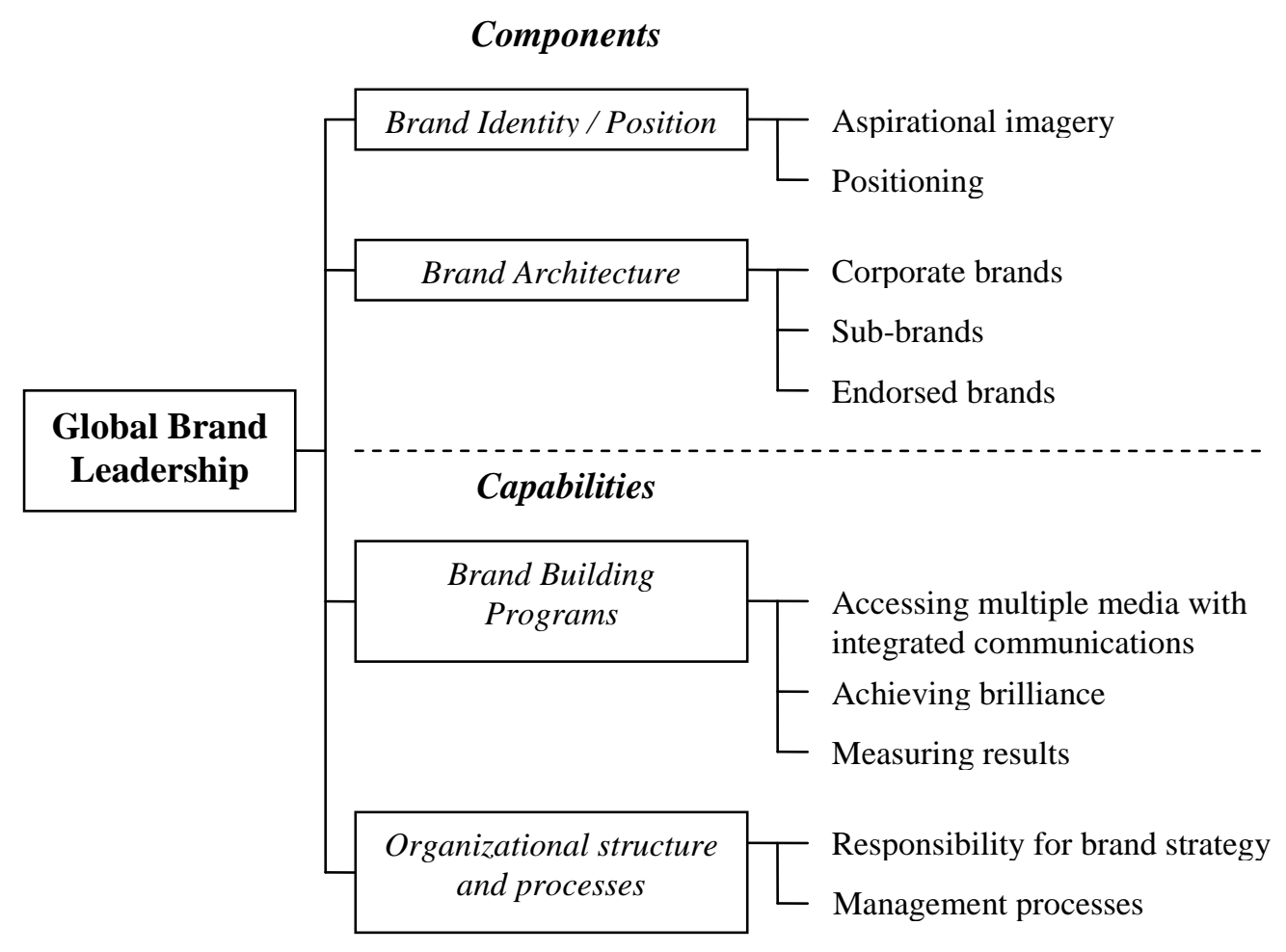

Source: Aaker, D.A. and Joachimsthaler, E. [2000] Brand Leadership, New York: Free Press, p. 5 
Table 1: Case Information and time spent in formal interviews / site visits

\begin{tabular}{|c|c|c|c|c|c|}
\hline Case Details & Fibre Co & Meat Co & Pharma Co & Fish Co & Dairy Co \\
\hline $\begin{array}{l}\text { Age of } \\
\text { brands }\end{array}$ & 10 years & 30 years & 100 years & 35 years & 21 years \\
\hline $\begin{array}{l}\text { Primary } \\
\text { customer }\end{array}$ & $\begin{array}{l}\text { Cloth } \\
\text { producers }\end{array}$ & $\begin{array}{l}\text { Restaurants, } \\
\text { supermarkets } \\
\text { and } \\
\text { specialist } \\
\text { retailers }\end{array}$ & $\begin{array}{l}\text { Pharmaceutical } \\
\text { companies }\end{array}$ & $\begin{array}{l}\text { Seafood } \\
\text { brands, } \\
\text { retailers }\end{array}$ & $\begin{array}{l}\text { Restaurants, } \\
\text { retailers, } \\
\text { airlines }\end{array}$ \\
\hline $\begin{array}{l}\text { Sales per } \\
\text { year }(2005)\end{array}$ & $\begin{array}{l}\text { NZ\$100 } \\
\text { million* }\end{array}$ & $\begin{array}{l}\text { NZ\$300 } \\
\text { million }\end{array}$ & $\begin{array}{l}\text { NZ\$12.3 } \\
\text { billion }\end{array}$ & $\begin{array}{l}\text { NZ\$300 } \\
\text { million }\end{array}$ & $\begin{array}{l}\mathrm{NZ} \$ 25 \\
\text { million }\end{array}$ \\
\hline Status & $\begin{array}{l}\text { Quality } \\
\text { leader; brand } \\
\text { of choice for } \\
\text { lead } \\
\text { customers }\end{array}$ & $\begin{array}{l}\text { Market } \\
\text { leader }\end{array}$ & $\begin{array}{l}\text { Market leader } \\
\text { in key markets; } \\
\text { one of handful } \\
\text { of large } \\
\text { players }\end{array}$ & $\begin{array}{l}\text { Quality } \\
\text { leader; brand } \\
\text { of choice for } \\
\text { lead } \\
\text { customers }\end{array}$ & $\begin{array}{l}\text { Quality } \\
\text { leader; brand } \\
\text { of choice for } \\
\text { lead } \\
\text { customers }\end{array}$ \\
\hline $\begin{array}{l}\text { Number of } \\
\text { countries in } \\
\text { which sales } \\
\text { occur }\end{array}$ & 35 & 52 & 140 & 50 & 15 \\
\hline $\begin{array}{l}\text { Number of } \\
\text { formal } \\
\text { interviews }\end{array}$ & 3 & 6 & 2 & 2 & 2 \\
\hline $\begin{array}{l}\text { Time spent } \\
\text { at case }\end{array}$ & 1 day & 2 days & 5 hours & 5 hours & 2 hours \\
\hline
\end{tabular}

* NZ\$1 = US\$0.70 approximately. 
Table 2: Global Brand Leadership Identity / Position and Architecture for all Cases

\begin{tabular}{|c|c|c|c|c|c|}
\hline $\begin{array}{l}\text { Global Brand } \\
\text { Leadership } \\
\text { Component }\end{array}$ & Fibre Co & Meat Co & Pharma Co & Fish Co & Dairy Co \\
\hline \multirow[t]{2}{*}{$\begin{array}{l}\text { Brand } \\
\text { Identity / } \\
\text { Position }\end{array}$} & $\begin{array}{l}\text { Identity: Pure, } \\
\text { innovative, highest } \\
\text { quality fibre from one } \\
\text { animal and country of } \\
\text { origin. }\end{array}$ & $\begin{array}{l}\text { Identity: Grade-A meat } \\
\text { subject to strict quality } \\
\text { controls and sourced from } \\
\text { one country-of-origin. }\end{array}$ & $\begin{array}{l}\text { Identity: Largest and cheapest } \\
\text { supplier of a complete range of } \\
\text { dairy products globally. }\end{array}$ & $\begin{array}{l}\text { Identity: Supplier of high quality } \\
\text { seafood ingredients, sourced } \\
\text { from one location and } \\
\text { sustainable management } \\
\text { practices of fish-stocks. }\end{array}$ & $\begin{array}{l}\text { Identity: The preeminent } \\
\text { supplier of specialty dairy } \\
\text { produce for corporate } \\
\text { customers. }\end{array}$ \\
\hline & $\begin{array}{l}\text { Position: strictly up- } \\
\text { market positioning, high } \\
\text { price, scarcity, supported } \\
\text { with certainty of supply } \\
\text { and customized } \\
\text { programs for major } \\
\text { buyers. }\end{array}$ & $\begin{array}{l}\text { Position: targeted as year } \\
\text { round, healthy, versatile } \\
\text { product at a high price. } \\
\text { Positioning also includes } \\
\text { adaptability and } \\
\text { preparedness to work with } \\
\text { channel members and users. }\end{array}$ & $\begin{array}{l}\text { Position: Aims to be the global } \\
\text { leader in the supply of milk } \\
\text { components products and } \\
\text { solutions. Desire to work with } \\
\text { leading pharmaceutical } \\
\text { companies in close partnership. }\end{array}$ & $\begin{array}{l}\text { Position: Aims to be global } \\
\text { leader of high quality, } \\
\text { environmentally friendly } \\
\text { seafood. Positioning also } \\
\text { includes working directly with } \\
\text { key customers to build strong } \\
\text { co-brands. }\end{array}$ & $\begin{array}{l}\text { Position: develops specialist } \\
\text { dairy products, sources others } \\
\text { globally, and targets the top- } \\
\text { end of any market. } \\
\text { Positioning includes working } \\
\text { directly with key customers to } \\
\text { build strong co-brands, and } \\
\text { with other like-minded } \\
\text { suppliers to provide a full } \\
\text { offering for customers. }\end{array}$ \\
\hline $\begin{array}{l}\text { Brand } \\
\text { Architecture }\end{array}$ & $\begin{array}{l}\text { One umbrella brand used } \\
\text { to endorse a number of } \\
\text { co-brands. }\end{array}$ & $\begin{array}{l}\text { Two brands, each targeted } \\
\text { at different channels. Both } \\
\text { brands supported by the } \\
\text { same quality programs. } \\
\text { Each brand endorses co- } \\
\text { brands. }\end{array}$ & $\begin{array}{l}\text { One umbrella brand endorses } \\
\text { multiple functional area brands. }\end{array}$ & One corporate ingredient brand. & One corporate brand. \\
\hline
\end{tabular}


Table 3: Global Brand Leadership Brand Building Programs and Supportive Structures and Processes for all Cases

\begin{tabular}{|c|c|c|c|c|c|}
\hline $\begin{array}{l}\text { Global Brand } \\
\text { Leadership } \\
\text { Component }\end{array}$ & Fibre Co & Meat Co & Pharma Co & Fish Co & Dairy Co \\
\hline \multirow[t]{3}{*}{$\begin{array}{l}\text { Brand } \\
\text { Building } \\
\text { Programs }\end{array}$} & $\begin{array}{l}\text { Accessing multiple } \\
\text { media; leveraging } \\
\text { network relationships to } \\
\text { build awareness; co- } \\
\text { branding; public } \\
\text { relations; leveraging } \\
\text { intangible brand assets. }\end{array}$ & $\begin{array}{l}\text { Accessing multiple media; } \\
\text { leveraging network } \\
\text { relationships to build } \\
\text { awareness; co-branding; } \\
\text { public relations. }\end{array}$ & $\begin{array}{l}\text { Accessing multiple media: } \\
\text { leveraging network } \\
\text { relationships; co-branded } \\
\text { alliances; public relations; } \\
\text { targeted marketing programs for } \\
\text { lead customers; integrated } \\
\text { marketing communications } \\
\text { (IMC) program globally. }\end{array}$ & $\begin{array}{l}\text { Accessing multiple media: } \\
\text { leveraging network } \\
\text { relationships; co-branded } \\
\text { alliances; public relations; } \\
\text { targeted marketing programs for } \\
\text { lead users; IMC. }\end{array}$ & $\begin{array}{l}\text { Accessing multiple media: } \\
\text { leveraging network } \\
\text { relationships; co-branded } \\
\text { alliances with customers and } \\
\text { suppliers; public relations; } \\
\text { targeted marketing support. }\end{array}$ \\
\hline & $\begin{array}{l}\text { Achieving brilliance } \\
\text { through accessing low } \\
\text { cost high impact } \\
\text { promotional activities } \\
\text { and constant increases } \\
\text { in product quality and } \\
\text { leveraging network } \\
\text { resources in new ways. }\end{array}$ & $\begin{array}{l}\text { Achieving brilliance } \\
\text { through accessing low cost } \\
\text { high impact promotional } \\
\text { activities and constant } \\
\text { increases in product quality. }\end{array}$ & $\begin{array}{l}\text { Achieving brilliance through co- } \\
\text { branded activities, and IMC } \\
\text { activities globally. Message } \\
\text { adapted to local contexts. }\end{array}$ & $\begin{array}{l}\text { Achieving brilliance through co- } \\
\text { branded promotions and IMC } \\
\text { activities. Message adapted to } \\
\text { local context. Works with } \\
\text { stakeholders to gain further } \\
\text { promotional opportunities. }\end{array}$ & $\begin{array}{l}\text { Achieving brilliance through } \\
\text { co-branded promotions, joint } \\
\text { promotion with other } \\
\text { complementary producers at } \\
\text { trade shows. Message adapted } \\
\text { to local context. }\end{array}$ \\
\hline & $\begin{array}{l}\text { Measuring results and } \\
\text { brand performance by } \\
\text { developing causal } \\
\text { feedback on separate } \\
\text { brand activities and } \\
\text { customers. Information } \\
\text { filtered back to } \\
\text { suppliers. }\end{array}$ & $\begin{array}{l}\text { Disconnect due to reliance } \\
\text { on a single, global measure } \\
\text { of brand impact. } \\
\text { Information filtered back to } \\
\text { suppliers although } \\
\text { information provided is of } \\
\text { limited use to enhance } \\
\text { customer-value. }\end{array}$ & $\begin{array}{l}\text { Measuring results and brand } \\
\text { performance with standard } \\
\text { financial and marketing metrics. } \\
\text { Information filtered back to } \\
\text { suppliers to guide improvements. }\end{array}$ & $\begin{array}{l}\text { Measuring results and brand } \\
\text { performance with standard } \\
\text { financial and marketing metrics. }\end{array}$ & $\begin{array}{l}\text { Measuring results and brand } \\
\text { performance with standard } \\
\text { financial and marketing } \\
\text { metrics. }\end{array}$ \\
\hline $\begin{array}{l}\text { Organizational } \\
\text { Structure and } \\
\text { Processes }\end{array}$ & $\begin{array}{l}\text { Responsibility for brand } \\
\text { strategy: cascading } \\
\text { ownership for the brand. }\end{array}$ & $\begin{array}{l}\text { Responsibility for brand } \\
\text { strategy: top leadership } \\
\text { support but disconnect with } \\
\text { suppliers. }\end{array}$ & $\begin{array}{l}\text { Responsibility for brand } \\
\text { strategy: top leadership support, } \\
\text { centralized brand team works } \\
\text { with regional areas to develop }\end{array}$ & $\begin{array}{l}\text { Responsibility for brand } \\
\text { strategy: one global brand } \\
\text { manager works directly with } \\
\text { regional partners. }\end{array}$ & $\begin{array}{l}\text { Responsibility for brand } \\
\text { strategy: one global brand } \\
\text { manager works directly with } \\
\text { lead users, and other alliance }\end{array}$ \\
\hline
\end{tabular}


Management processes: Management processes: adaptability to

individual customers

and network partners

across nations; constant

product and marketing

innovation.

customers and network

partners across nations;

innovation.
Management processes:

adaptability to key customers

and markets; constant marketing

innovation.
Management processes:

adaptability to key customers

and markets; constant marketing

innovation; lobbying for

sustainable fishing practices.
Management processes:

adaptability to key customers

and markets; constant

marketing and product

innovation; public and trade

education on dairy foods. 